\title{
GROWTH AND PHYSIOLOGICAL ATTRIBUTES OF Cordia trichotoma SEEDLINGS IN RESPONSE TO FERTILIZATION WITH PHOSPHORUS AND POTASSIUM
}

\author{
Álvaro Luís Pasquetti Berghetti ${ }^{1 *}$, Maristela Machado Araujo ${ }^{1}$, Luciane Almeri Tabaldi ${ }^{2}$, Daniele Guarienti \\ Rorato ${ }^{3}$, Suelen Carpenedo Aimi ${ }^{1}$, Júlia Gomes Fárias ${ }^{2}$ \\ ${ }^{1}$ Federal University of Santa Maria, Departament of Forest Sciences, Santa Maria, Rio Grande do Sul, Brazil - alvaro.berghetti@ gmail.com*; \\ araujo.maristela@gmail.com; suaimi@gmail.com. \\ ${ }^{2}$ Federal University of Santa Maria, Departament of Biology, Santa Maria, Rio Grande do Sul, Brazil - lutabaldi@ yahoo.com.br; \\ fariasjuliag@hotmail.com. \\ ${ }^{3}$ State University of the West of Paraná, Departament of Agrarian Sciences, Cândido Rondon, Paraná, Brazil - dannirorato@ hotmail.com.
}

Received for publication: 15/02/2018 - Accepted for publication: 10/05/2018

\begin{abstract}
The cultivation of native tree species of economic and environmental interest, such as Cordia trichotoma, still depends on nutritional information. This study aimed to identify the effect of phosphorus (P) and potassium (K) application on the growth and photosynthetic activity of seedlings of Cordia trichotoma. In a greenhouse, ten treatments were tested considering three levels of $\mathrm{P}\left(150,300\right.$, and $\left.450 \mathrm{mg} \mathrm{dm}^{-3}\right)$, three of $\mathrm{K}(50,100$, and $150 \mathrm{mg} \mathrm{dm}^{-3}$ ) and a control sample (with no fertilization). Pots filled with Red Argisol were used. At 180 days after prick, the following variables were evaluated: shoot height, stem diameter, area dry matter, root dry weight, leaf area, chlorophyll $a$ fluorescence and photosynthetic pigments. The supplementation with $\mathrm{P}$ and $\mathrm{K}$ promoted increased growth and photosynthetic capacity of the seedlings. The treatment with $450 \mathrm{mg} \mathrm{dm}^{-3}$ of $\mathrm{P}$ and $50 \mathrm{mg} \mathrm{dm}^{-3}$ of $\mathrm{K}$ provided the highest growth and the best use of the light energy by the photosystem II $(\mathrm{Fv} / \mathrm{Fm}=0.76)$, as well as lower energy loss index $(\mathrm{Fo}=172.5)$. It is recommended the application of $450 \mathrm{mg}$ $\mathrm{dm}^{-3}$ of $\mathrm{P}$ and $50 \mathrm{mg} \mathrm{dm}{ }^{-3}$ of $\mathrm{K}$, with the aim at higher growth and photosynthetic rate of seedlings of $C$. trichotoma.
\end{abstract}

Keywords: Louro-pardo, Boraginaceae, tropical arboreal species, fluorescence.

\section{Resumo}

Crescimento e eficiência fotossintética de mudas de Cordia trichotoma em resposta à adubação com fósforo $e$ potássio. $\mathrm{O}$ cultivo de espécies arbóreas nativas de interesse econômico e ambiental, como Cordia trichotoma, ainda depende de informações nutricionais. Assim, este estudo teve como objetivo avaliar o efeito da aplicação de fósforo $(\mathrm{P})$ e potássio $(\mathrm{K})$ no crescimento e na atividade fotossintética de mudas de Cordia trichotoma. Em casa de vegetação, foram testados dez tratamentos, considerando três níveis de $\mathrm{P}$ $\left(150,300\right.$ e $\left.450 \mathrm{mg} \mathrm{dm}^{-3}\right)$, três de $\mathrm{K}\left(50,100\right.$ e $\left.150 \mathrm{mg} \mathrm{dm}^{-3}\right)$ e testemunha (sem adubação). Foram utilizados vasos preenchidos com Argissolo Vermelho. Aos 180 dias após repicagem, as seguintes variáveis foram avaliadas: altura, diâmetro do coleto, matéria seca aérea, matéria seca radicular, área foliar, fluorescência da clorofila $a$ e pigmentos fotossintéticos. A suplementação com $\mathrm{P}$ e K promoveu aumento no crescimento e na capacidade fotossintética das mudas. $\mathrm{O}$ tratamento com $450 \mathrm{mg} \mathrm{dm}^{-3}$ de $\mathrm{P}$ e $50 \mathrm{mg} \mathrm{dm}^{-3}$ de $\mathrm{K}$ proporcionou o maior crescimento e o melhor aproveitamento da energia luminosa pelo fotossistema II $\left(\mathrm{F}_{\mathrm{v}} / \mathrm{F}_{\mathrm{m}}=0,76\right)$, bem como menor índice de perda de energia $(\mathrm{Fo}=172,5)$. Recomenda-se a aplicação de $450 \mathrm{mg} \mathrm{dm}^{-3}$ de $\mathrm{P}$ e 50 $\mathrm{mg} \mathrm{dm}^{-3} \mathrm{de} \mathrm{K}$ visando maior crescimento e maior taxa fotossintética das mudas de C. trichotoma.

Palavras-chave: Louro-pardo, Boraginaceae, espécie arbórea tropical, fluorescência.

\section{INTRODUCTION}

Studies related to the morphophysiological performance of tropical tree species with commercial and ecological potential are incipient, mainly in respect to the demand of essential nutrients for the growth of these individuals in field planting. Among these species, Cordia trichotoma (Vell.) Arrab. ex Steud stands out, popularly known as louro-pardo, and it is widely distributed in tropical and subtropical forests in Brazil, Argentina, Paraguay, Uruguay and Bolivia. This species is recognized for the quality of its wood, which is used in the construction of luxury furniture, decorative covers and civil construction by presenting easy workability, classifying it with high commercial value. In addition, by having relatively fast growth, can be employed in plantations intended for restoration of degraded areas and commercial purposes (CADORIN et al., 2015; CORADIN et al., 2011).

FLORESTA, Curitiba, PR, v. 49, n. 1, p. 133-142, jan/mar 2019 
Most afforestation and reforestation projects are inserted in areas with low natural fertility and essential macronutrients deficiency, such as phosphorus (P) and potassium (K) (GONÇALVES et al., 2008a, GONÇALVES et al., 2008b). This can slow the development of seedlings of the species $C$. trichotoma because in nutritional terms these elements perform fundamental functions to growth by being involved in respiratory and photosynthetic activity process (TAIZ; ZEIGER, 2013). Thus, when diagnosed the need, the fertilization to provide nutrients to the plants becomes essential (ROSSA et al., 2014).

$\mathrm{P}$ is one of the most limiting nutrients in plant productivity (GERKE, 2015; MARSCHNER, 2012) and exerts great influence on the growth of seedlings of tree species of ecological and commercial interest (SOUZA et al., 2013; STAHL et al., 2013) by fact of participating in processes and cellular metabolites, as a constituent of enzymes, adenosine triphosphate and integrate the process of energy transfer and storage (TAIZ; ZEIGER, 2013). $\mathrm{K}$ is a macronutrient essential for plant growth and development, playing an important role in physiological processes (OOSTERHUIS et al., 2013) as a regulator of the osmotic potential of plant cells and activation of enzymes involved in respiration and photosynthesis, besides acting in the maintenance of the turgidity of the guard cells (TAIZ; ZEIGER, 2013).

Due to the importance of these macronutrients in plant metabolism and to the scarcity of information on the nutritional, morphologic and physiological aspects of the species C. trichotoma, it becomes important the execution of studies that consider such characteristics. As hypothesis, it is expected the increase of the availability of $\mathrm{P}$ and $\mathrm{K}$ to positively affect the growth of $C$. trichotoma seedlings. With the purpose of establishing morphophysiological indicators that help in the planting planings, the objective of this study was to evaluate the effect of applying $\mathrm{P}$ and $\mathrm{K}$ in the growth and photosynthetic activity of $C$. trichotoma seedlings.

\section{MATERIAL AND METHODS}

The experiment was conducted in a greenhouse at the Federal University of Santa Maria (UFSM), located in the municipality of Santa Maria (state of Rio Grande do Sul, Brazil) $\left(29^{\circ} 43^{\prime} 15^{\prime \prime} \mathrm{S}\right.$ and $53^{\circ} 43^{\prime}$ $18^{\prime \prime} \mathrm{W}$ ), in the period from November 2012 to June 2013. The average temperature inside the greenhouse was $27.4{ }^{\circ} \mathrm{C}$ and the average relative humidity was $79 \%$. The study site is located in the physiographic region of the Depressão Central of the State of Rio Grande do Sul, with an altitude of approximately 90 meters. The climate is classified as Cfa according to Köppen (ALVARES et al., 2013).

The seeds used were from diaspores collected on October $2^{\text {nd }}, 2012$ in fragments of Seasonal Deciduous Forest ( $29^{\circ} 45^{\prime} 22^{\prime \prime} \mathrm{S}$ and $\left.53^{\circ} 34^{\prime} 47^{\prime \prime} \mathrm{W}\right)$. Immediately after collection, the extraction was carried out, processing and sowing diaspores in trays containing vermiculite substrate. Approximately 50 days after sowing (11/20/2012), the seedlings that presented the cotyledons and the eophyll developed were replanted in polypropylene vases containing $2.5 \mathrm{dm}^{3}$ of soil.

The soil used to fill the vessels was a Typical Red Dystrophic Argisol (EMBRAPA, 2013), with sandy texture and low bases saturation (Table 1). Soil collection occurred in a 0 to $20 \mathrm{~cm}$ depth layer at the UFSM campus $\left(29^{\circ} 43^{\prime} 02 \mathrm{~S}\right.$ and $\left.53^{\circ} 43^{\prime} 38 \mathrm{~W}\right)$. After collection, the soil was dried in an aerated and sifted place $(4 \mathrm{~mm}$ mesh). It was subsequently kept in an oven at $60^{\circ} \mathrm{C}$ until constant weight.

Table 1. Physical and chemical attributes of the soil used in the production of Cordia trichotoma seedlings, in the municipality of Santa Maria (Rio Grande do Sul, Brazil).

Tabela 1. Atributos físico e químicos do solo usados na produção de mudas de Cordia trichotoma, no município de Santa Maria (Rio Grande do Sul, Brasil).

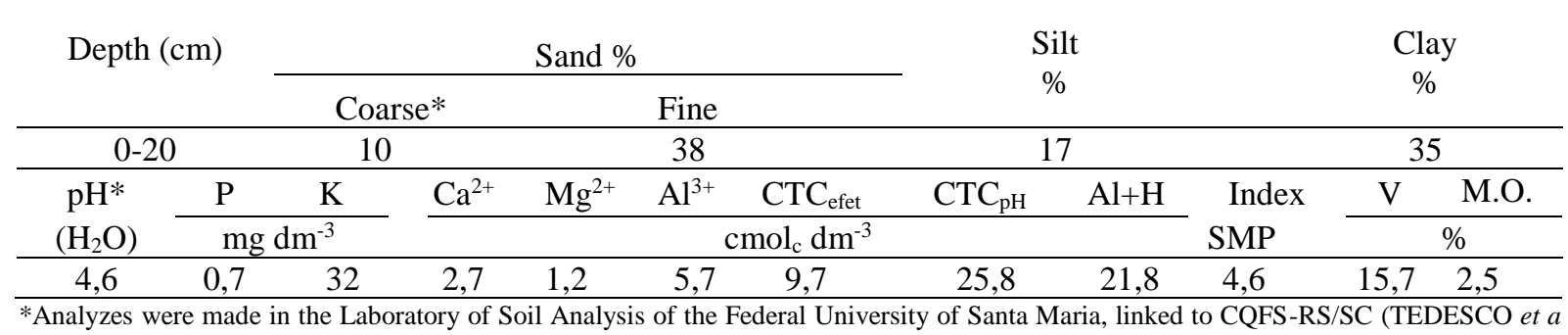
1., 1995).

Ten combinations were tested in a completely randomized design with six replicates, composed by three P levels (150, 300 and $\left.450 \mathrm{mg} \mathrm{dm}^{-3}\right)$ and three $\mathrm{K}$ levels (50, 100 and $150 \mathrm{mg} \mathrm{dm}^{-3}$ ) with $100 \mathrm{mg} \mathrm{dm}^{-3}$ of $\mathrm{N}$ in all combinations, in addition to the control treatment, which did not receive fertilization. The salts used as a source 
of $\mathrm{P}, \mathrm{K}$, and $\mathrm{N}$ were the phosphorus pentoxide $\left(\mathrm{P}_{2} \mathrm{O}_{5}\right)$, potassium chloride $(\mathrm{KCl})$ and ammonium nitrate $\left(\mathrm{NH}_{4} \mathrm{NO}_{3}\right)$, respectively.

Irrigation in the vessels was held daily with distilled water, keeping soil moisture in $60 \%$ of field capacity (c.c.). The measurements concerning the need and amount of water applied in the vessels were performed daily by means of vessels weighing in analytical balance (accuracy of $0.001 \mathrm{~g}$ ). Weekly, the calibration of the vessels to preset c.c. was made.

At 180 days after pricking out (d.a.r), the morphologic attributes were measured: shoot height $(\mathrm{H})$, stem diameter (SD), area dry matter (ADM), root dry matter (RDM) and leaf area (LA), and the physiological attributes tenor of chlorophyll $a(\mathrm{Chl} a)$, chlorophyll $b(\mathrm{Chl} b)$, carotenoids and chlorophyll $a$ fluorescence. The $\mathrm{H}$ was obtained with the aid of a millimeter rule and the SD, with digital caliper $(0.01 \mathrm{~mm}$ accuracy). Then, the plants were divided into shoot and root to obtain the ADM and RDM values, and the roots were washed in running water on sieve (1 mm mesh). The samples were placed in paper bags and allocated in an air exchanged oven at temperature of $70^{\circ} \mathrm{C}$ until reaching constant dry matter, then weighted in analytical balance $(0.001 \mathrm{~g})$.

For determination of LA, the leaves were distributed on paper A4 with millimetric scale, pressed by transparent glass and photographed with a digital camera (SONY Cyber-shot 8.1 megapixels) with 1.4x zoom at a shoot height of $50 \mathrm{~cm}$. Later, the images have been processed in the software Image $\mathrm{J}$.

The evaluation of Chl $a$ and $\mathrm{Chl} b$ tenors as well as carotenoids was obtained from the fourth expanded leaf. After collection, the leaves were immediately frozen in liquid $\mathrm{N}_{2}$ and subsequently stored in ultra-freezer at $-80{ }^{\circ} \mathrm{C}$ until the moment of quantification, which was performed at the Plant Biotechnology Laboratory of the Department of Biology of the UFSM. The concentrations of these pigments had been determined in agreement described methodology by Hiscox and Israelstam (1979) and estimated using the formula of Lichtenthaler (LICHTENTHALER, 1987). The fresh leaf samples $(0.05 \mathrm{~g})$ were incubated the $65^{\circ} \mathrm{C}$ with dimethyl sulfoxide (DMSO) for two hours, and the supernate absorbance was read at 663 (chlorophyll $a$ ), 645 (chlorophyll $b$ ) and $470 \mathrm{~nm}$ (carotenoids) had been determined in spectrophotometer model SF325NM (Bel Engineering, Italy).

The measurement of fluorescence emission of chlorophyll $a$ occurred between seven and ten hours in the morning, with sun and without presence of clouds, using the fourth expanded leaf. First, the leaves were wrapped in aluminum foil for 30 minutes before each assessment for adaptation to the dark. Later, the analyses were conducted with the aid of modulated light fluorometer JUNIOR-PAM (Walz, Germany), obtaining the initial fluorescence $\left(\mathrm{F}_{0}\right)$, maximum fluorescence $\left(\mathrm{F}_{\mathrm{m}}\right)$ and maximum quantum yield $\left(\mathrm{F}_{\mathrm{v}} / \mathrm{F}_{\mathrm{m}}\right)$.

The data were analyzed according to the assumptions of normality and homogeneity of variance by the Shapiro-Wilk and Bartlett tests, respectively. Subsequently, the analysis of variance (ANOVA) was performed followed by the comparison of averages by Scott-Knott test at 5\% probability of error through the Sisvar statistical software (FERREIRA, 2011).

\section{RESULTS}

The addition of $\mathrm{P}$ and $\mathrm{K}$ in the soil was favorable to seedling growth of $C$. trichotoma. The variables $\mathrm{H}$ $(p<0.0001)$ and $\mathrm{SD}(p<0.0001)$ followed a similar trend in response to treatments, the highest values being obtained in the treatments with $450 \mathrm{mg} \mathrm{dm}^{-3}$ of $\mathrm{P}$ combined with 50 and $100 \mathrm{mg} \mathrm{dm}^{-3}$ of $\mathrm{K}$. In control treatment and in those that received the lowest $\mathrm{P}$ levels $\left(150 \mathrm{mg} \mathrm{dm}^{-3}\right)$, plant growth was lower, providing the lower averages for $\mathrm{H}$ and SD (Figures 1A and 1B). The treatment with the combination of $450 \mathrm{mg} \mathrm{dm}^{-3} \mathrm{P}$ and $50 \mathrm{mg}$ $\mathrm{dm}^{-3} \mathrm{~K}$ provided major production of $\mathrm{ADM}(p<0.0001)$, RDM $(p<0.0001)$ and LA $(p<0.0001)$, resulting $11.64 \mathrm{~g}, 11.52$ and $2004.20 \mathrm{~cm}^{2}$, respectively, and differed from other treatments (Figures 1C, 1D and 1E).

In General, it is noticeable the existence of four growth trends for C. trichotoma seedlings, proportional to the increased of $\mathrm{P}$ levels (Figure 1). Control treatment resulted in the lowest values for the morphological attributes $(\mathrm{H}, \mathrm{SD}, \mathrm{ADM}, \mathrm{RDM}, \mathrm{LA})$, and the major averages elapsed from combinations with the highest $\mathrm{P}$ concentration. However, the treatments with $450 \mathrm{mg} \mathrm{dm}^{-3}$ of $\mathrm{P}$ combined with doses of $\mathrm{K}$ above $50 \mathrm{mg} \mathrm{dm}^{-3}$ decreased morphological attributes (Figure 1).

FLORESTA, Curitiba, PR, v. 49, n. 1, p. 133-142, jan/mar 2019. 

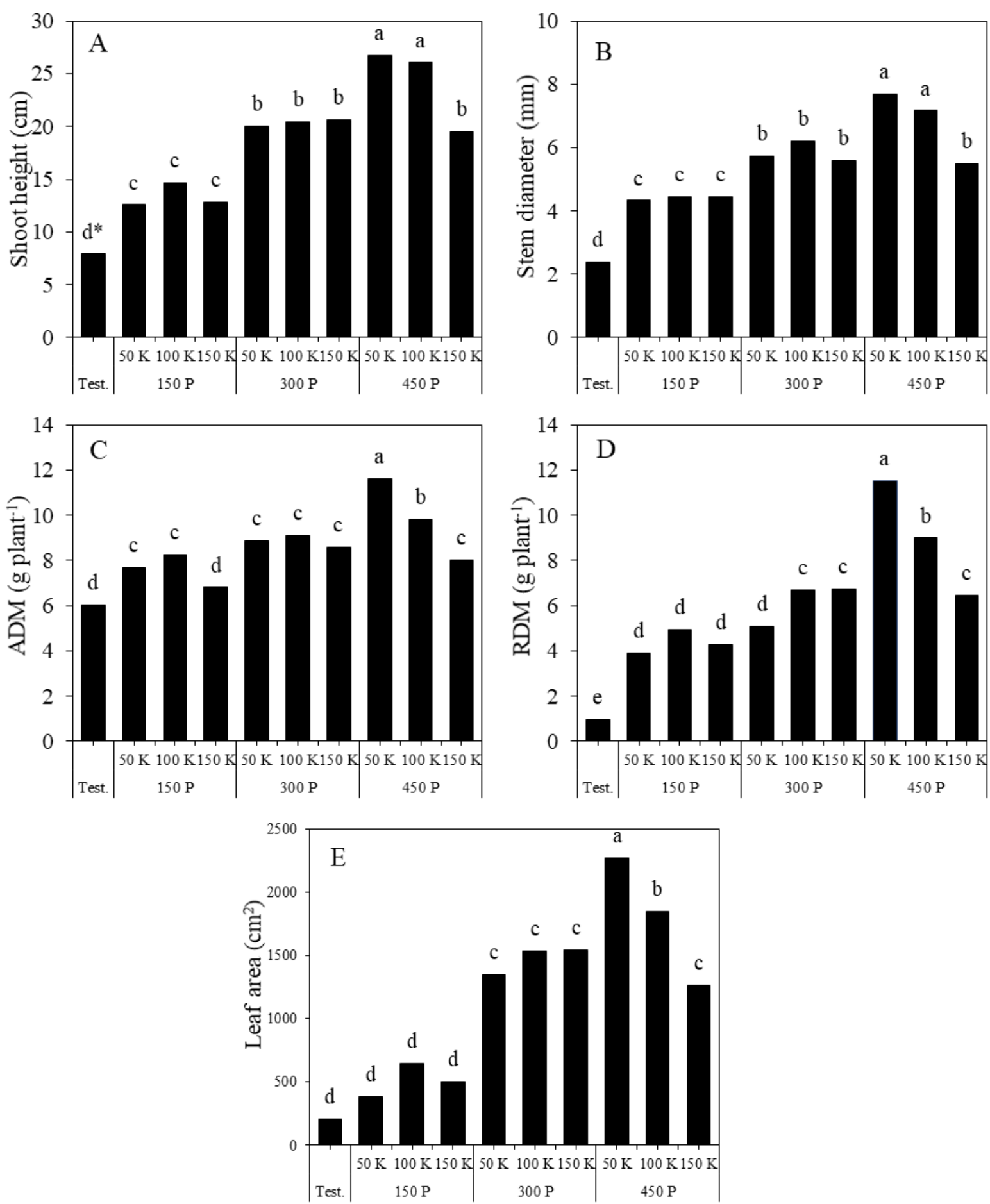

The averages not followed by the same letter differ between themselves by Scott-Knott test at 5\% probability level.

Figure 1. Effect of the different doses of phosphorus $(\mathrm{P})$ and potassium $(\mathrm{K})$ on shoot height (A), stem diameter (B), area dry matter (C), root dry weight (D) and leaf area (E) of seedlings of Cordia trichotoma, 180 days after pricking out.

Figura 1. Efeito das diferentes doses de fósforo $(\mathrm{P})$ e potássio $(\mathrm{K})$ na altura da parte aérea (A), diâmetro do coleto (B), massa seca da parte aérea (C), massa seca da raiz (D) e área foliar (E) das plântulas Cordia trichotoma, 180 dias após a perfuração. 
The treatments influenced levels of chlorophyll $a$ (Chl $a ; p<0.0001)$, chlorophyll $b(\mathrm{Chl} b ; p<0.0001)$ e carotenoids $(p<0.0001)$. Treatment with $450 \mathrm{mg} \mathrm{dm}^{-3}$ of $\mathrm{P}$ and $50 \mathrm{mg} \mathrm{dm}^{-3}$ of $\mathrm{K}$ provided the largest concentrations of Chl $a$, Chl $b$ and carotenoids, with averages of $1.35,0.42$ e $0.42 \mathrm{mg} \mathrm{g}^{-1} \mathrm{FW}$, respectively. The plants grown in the other treatments presented the smallest averages of these pigments in relation to this combination (Figures 2A, 2B and 2C).
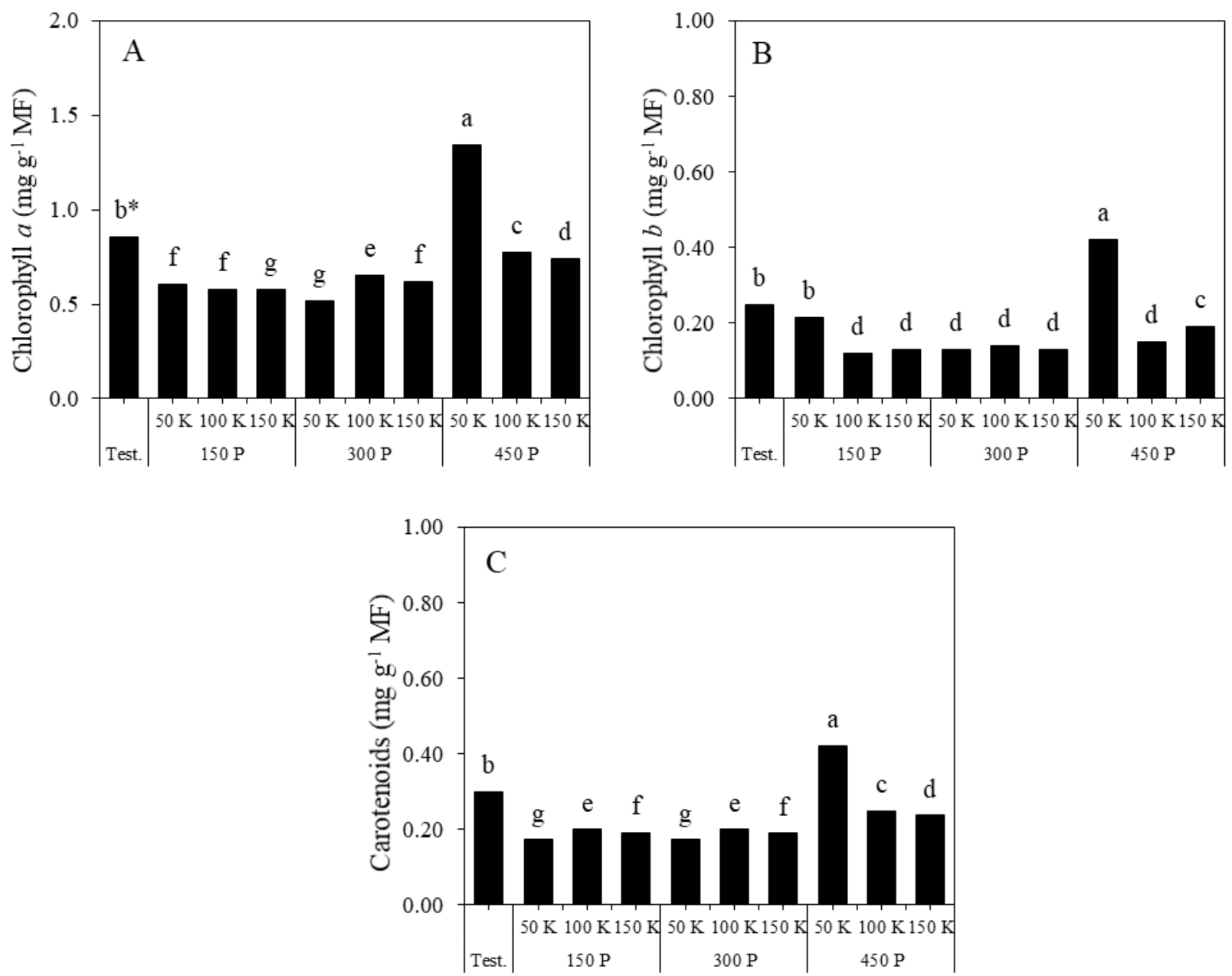

The averages followed by the same letter indicate that the treatment do not differ between themselves by Scott-Knott test at $5 \%$ probability level.

Figure 2. Effect of different doses of phosphorus (P) and potassium (K) on chlorophyll $a$ (A), chlorophyll $b$ (B) and carotenoids (C) of seedlings of Cordia trichotoma, 180 days after pricking out.

Figure 2. Efeito de diferentes doses de fósforo (P) e potássio (K) na clorofila a (A), clorofila b (B) e carotenóides (C) de plântulas de Cordia trichotoma, 180 dias após a perfuração.

The chlorophyll $a$ fluorescence attributes of $C$. trichotoma seedlings were influenced by the increasing of availability of $\mathrm{P}$ and $\mathrm{K}$. The initial fluorescence $\left(\mathrm{F}_{\mathrm{o}}\right)$ showed that the use of $450 \mathrm{mg} \mathrm{dm}^{-3}$ of $\mathrm{P}$ and $50 \mathrm{mg} \mathrm{dm}^{-3}$ of $\mathrm{K}\left(\mathrm{F}_{\mathrm{o}}=172,5\right)$ presented the lowest photochemical energy loss rate $(p<0.0001)$ (Figure $\left.3 \mathrm{~A}\right)$; while at maximum fluorescence $\left(\mathrm{F}_{\mathrm{m}}\right)$, it was observed that the combined use of $450 \mathrm{mg} \mathrm{dm}^{-3}$ of $\mathrm{P}$ and 50 and $100 \mathrm{mg} \mathrm{dm}^{-3}$ of $\mathrm{K}$ along with $150 \mathrm{mg} \mathrm{dm}^{-3}$ of $\mathrm{P}$ and $150 \mathrm{mg} \mathrm{dm}^{-3}$ of $\mathrm{K}$ in the control showed lower dissipation of energy in the PSII antenna complex $(p=0.0114)$ (Figure 3B).

The maximum quantum yield $\left(\mathrm{F}_{\mathrm{v}} / \mathrm{F}_{\mathrm{m}}\right)$ of photosystem II (PSII) was influenced $(p<0.0001)$ by the combinations of nutrients present in the treatments, ranging from 0.39 and 0.76 . Similarly, for the contents of photosynthetic pigments, the combination of $450 \mathrm{mg} \mathrm{dm}^{-3}$ of $\mathrm{P}$ and $50 \mathrm{mg} \mathrm{dm}^{-3}$ of $\mathrm{K}$ provided the highest maximum quantum yield of PSII (Figure 3C).

FLORESTA, Curitiba, PR, v. 49, n. 1, p. 133-142, jan/mar 2019 

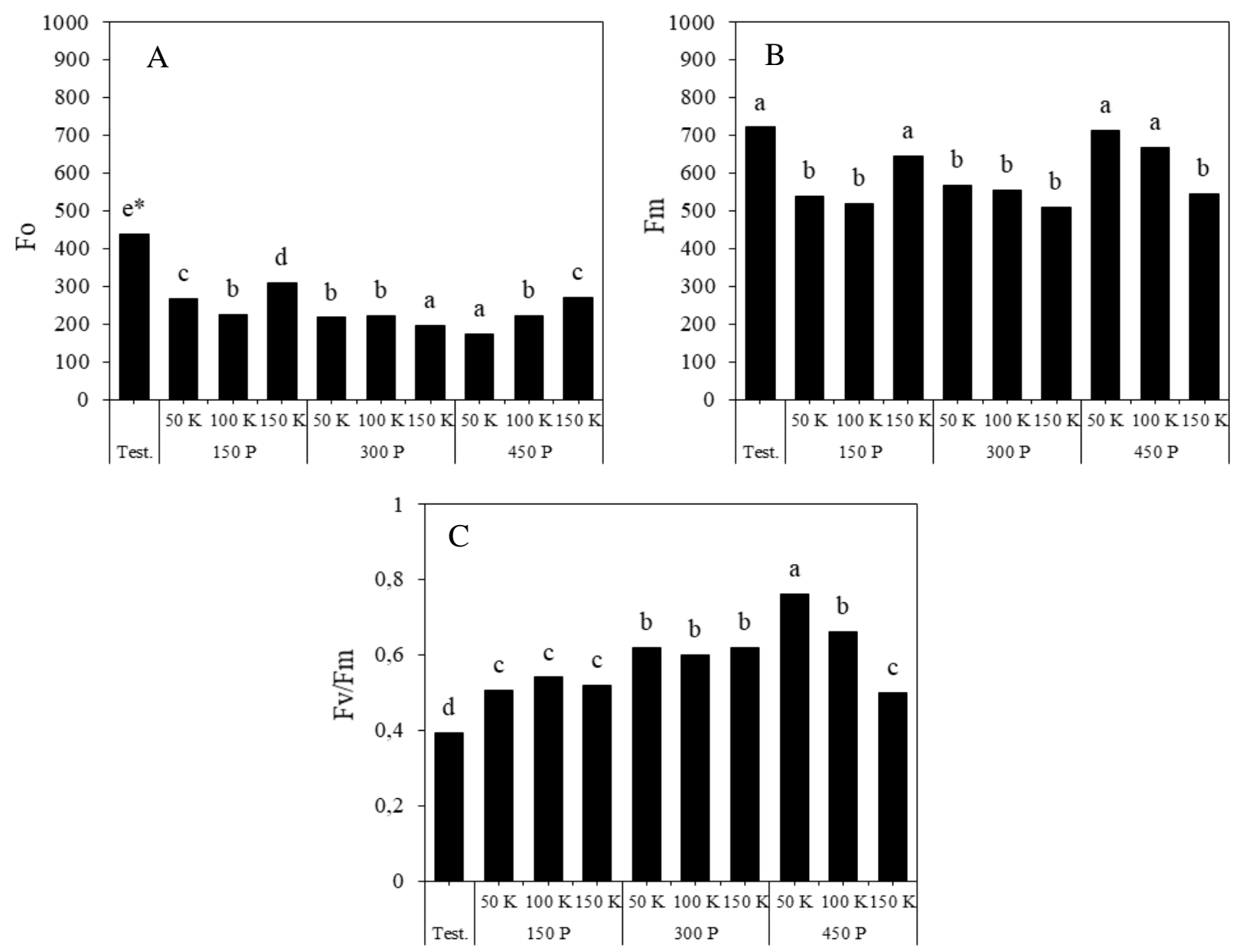

The averages followed by the same letter indicate that the treatment do not differ between themselves by Scott-Knott test at $5 \%$ probability level.

Figure 3. Effect of different doses of phosphorus $(\mathrm{P})$ and potassium $(\mathrm{K})$ on the physiological variables initial fluorescence $\left(\mathrm{F}_{\mathrm{o}}\right)(\mathrm{A})$, maximum fluorescence $\left(\mathrm{F}_{\mathrm{m}}\right)(\mathrm{B})$ and maximum quantum yield $\left(\mathrm{F}_{\mathrm{v}} / \mathrm{F}_{\mathrm{m}}\right)(\mathrm{C})$ of seedlings of Cordia trichotoma, 180 days after pricking out.

Figure 3. Efeito de diferentes doses de fósforo $(\mathrm{P})$ e potássio $(\mathrm{K})$ nas variáveis fisiológicas fluorescência inicial $(\mathrm{Fo})(\mathrm{A})$, fluorescência máxima $(\mathrm{Fm})(\mathrm{B})$ e rendimento quântico máximo $(\mathrm{Fv} / \mathrm{Fm})(\mathrm{C})$ de plântulas de Cordia trichotoma, 180 dias após a perfuração.

\section{DISCUSSION}

The positive response to fertilization observed in the morphological attributes of C. trichotoma seedlings reflects the requirement of the species in relation to soil fertility, with restriction on the growth of both shoot and root area under inadequate nutrition (Figures 1A, 1B, 1C, 1D and 1E). This condition is imposed by low natural soil fertility (Table 1), characteristic of tropical and subtropical regions soils (GONÇALVES et al., 2008a; GONÇALVES et al., 2008b), and the species potential growth.

The influence of $\mathrm{P}$ and $\mathrm{K}$ is noticeable in morphological attributes and it was supported by the physiological results, which have shown, by means of fluorescence analysis of chlorophyll $a$, that the largest photochemical energy loss occurred in the treatment without $\mathrm{P}$ and $\mathrm{K}$ supplementation (Figure 3A). This indicates damage to the reaction center of PSII or reduction in transference of energy excited from light collector system to the reaction center (BAKER, 2008), suggesting photosynthetic stress in plants caused possibly by the nutritional restriction.

The growth in $\mathrm{H}$ and $\mathrm{SD}$ of the seedlings (Figures $1 \mathrm{~A}$ and 1B), coupled with the lowest rate of photochemical energy loss (Figure 3A) using $450 \mathrm{mg} \mathrm{dm}^{-3}$ of $\mathrm{P}$ e $50 \mathrm{mg} \mathrm{dm}^{-3}$ of $\mathrm{K}$, show the response of the 
species $C$. trichotoma to fertilization, mainly regarding the use of $\mathrm{P}$ because when this element is available in low doses $\left(150\right.$ e $300 \mathrm{mg} \mathrm{dm}^{-3}$ ), there are limitations both on growth and photosynthetic efficiency (Figures 1 and 3).

Higher production of ADM and RDM in the treatment with $450 \mathrm{mg} \mathrm{dm}^{-3}$ of $\mathrm{P}$ e $50 \mathrm{mg} \mathrm{dm}^{-3}$ of K show that $\mathrm{P}$ contributed to the accumulation of dry matter in plants (SOUZA et al., 2014). This increase could be due to the influence that this nutrient has on the photosynthetic rate, especially in the Calvin Cycle activity and regeneration of the Rubisco enzyme (MARSCHNER, 2012; TAIZ; ZEIGER, 2013). In addition, the increase in $\mathrm{P}$ and $\mathrm{K}$ supply has been correlated to the greater water use efficiency (TAIZ; ZEIGER, 2013), contributing to biomass accumulation in the plants.

The largest LA was observed in seedlings subjected to treatment with the higher dose of $\mathrm{P}$ and lower dose of $\mathrm{K}$ (Figure 1E). Thus, it is believed that cultivated plants with higher levels of $\mathrm{P}$ may present higher growth rates in the field, because the photosynthetic process is influenced by the dimensions of the photoassimilator system. This way, plants with greater AF are able to intercept more light energy, converting it to chemical energy (CROUS et al., 2015). At the same time, the greatest concentrations of photosynthetic pigments (Figures 3A, 3B and 3C) in seedlings of C. trichotoma subjected to $450 \mathrm{mg} \mathrm{dm}^{-3}$ of $\mathrm{P}$ and $50 \mathrm{mg} \mathrm{dm}^{-3}$ of $\mathrm{K}$ represent greater photosynthetic efficiency, since high concentrations of Chl $a$ e Chl $b$ reflected higher photosynthetic rates (TAIZ; ZEIGER, 2013). Changes in the contents of photosynthetic pigments are induced by the low level of P (JIANG et al.., 2009), being the reduction synthesis of these pigments often observed in plants grown in soils with low $\mathrm{P}$ availability.

The growth of morphological attributes (H, SD, ADM, RDM and LA) proportional to the increasing levels of $\mathrm{P}$ (Figure 1) is compatible to the observed maximum quantum yield $\left(\mathrm{F}_{\mathrm{v}} / \mathrm{F}_{\mathrm{m}}=0.76\right.$ ) of PSII (Figure $3 \mathrm{C}$ ), showing the greatest utilization of light energy by PSII observed in the combination of $450 \mathrm{mg} \mathrm{dm}^{-3}$ of $\mathrm{P}$ and 50 $\mathrm{mg} \mathrm{dm}{ }^{-3}$ of $\mathrm{K}$. However, when $\mathrm{P}$ and $\mathrm{K}$ are not available in the soil (control treatment), $\mathrm{F}_{\mathrm{v}} / \mathrm{F}_{\mathrm{m}}$ is reduced in percentages greater than $50 \%$, indicating a possible damage to PSII in and confirming the importance of these nutrients to the growth of $C$. trichotoma seedlings.

$F_{v} / F_{m}$ is a robust attribute compared to $F_{o}$ and $F_{m}$, capable of indicating the existence of damages and the maximum quantum efficiency of PSII (BAKER, 2008). So, it demonstrates the ability of the PSII in to capture radiant energy and transfer it to the photochemical reactions responsible for the synthesis of NADPH. Healthy plants, without exposure to biotic or abiotic stress, usually present values between 0.75 and 0.85 . This result varies between species, and much inferior results are indicative of PSII reduced photochemical ability (AGUILAR; DEMINICIS, 2009).

To C. trichotoma species, the measurement of fluorescence emission of chlorophyll $a$ was an effective technique, able to quantify tolerance of plants to stress caused by nutritional deficiency. Such diagnosis can be performed quickly and accurately through the absorption and utilization of light energy by PSII (BAKER, 2008). Thus, before the appearance of any morphological damage, the photosynthetic apparatus, particularly PSII, can be affected (PANDA et al., 2008). Thus, these changes can be detected by this analysis, allowing a stress estimation of the photosynthetic apparatus of the plants.

Doses of 150 and $300 \mathrm{mg} \mathrm{dm}{ }^{-3}$ of $\mathrm{P}$ are insufficient for adequate photosynthetic activity of $C$. trichotoma seedlings regardless of $\mathrm{K}$ dosage used. Considering this, it is perceptible that the largest dose of $\mathrm{P}$, but using the lower level of $\mathrm{K}$, provides the best nutritional conditions for the plants. When it is applied quantities exceeding $50 \mathrm{mg} \mathrm{dm}{ }^{-3}$ of $\mathrm{K}$ for the higher dose of $\mathrm{P}$, there is a decrease in the growth and physiological attributes efficiency and consequently in the seedlings photosynthetic activity. Excess of $\mathrm{K}$ can inhibit the absorption of magnesium, boron, zinc and ammonia by the roots and their mobilization to the shoot (SUN; PAYN, 1999; TAIZ; ZEIGER, 2013). This can reduce the synthesis of photosynthetic pigments and the maximum quantum yield of PSII, causing decrease in growth (TAIZ; ZEIGER, 2013).

In this study, in general, the addition of $\mathrm{P}$ and $\mathrm{K}$ provided benefits in the morphological and physiological parameters of the seedlings of $C$. trichotoma. It is realized that this species is more responsive to $\mathrm{P}$ than to $\mathrm{K}$ and that doses up to $50 \mathrm{mg} \mathrm{dm}^{-3}$ of $\mathrm{K}$ are sufficient for its growth. Larger doses can cause toxicity and, as consequence, lead to a reduction of the growth of these plants. It is distinguished the existence of four trends of growth, proportional to the increase of the levels of $\mathrm{P}$. The dose of $450 \mathrm{mg} \mathrm{dm}^{-3}$ of $\mathrm{P}$ caused the biggest values of the morphologic parameters shoot height, stem diameter, production of root and area dry matter. Moreover, the photosynthetic pigments and the emission of chlorophyll $a$ had also presented the best averages in the plants cultivated in soil with greater availability of $\mathrm{P}$.

FLORESTA, Curitiba, PR, v. 49, n. 1, p. 133-142, jan/mar 2019 
It is inferible that, with this information, it is possible to produce higher-quality plants, less susceptible to post planting stresses. In addition, this study allowed to deduce that plantations in the field with the species $C$. trichotoma in low-P soils can be made once there is the increasing of $\mathrm{P}$ availability through phosphates addition. However, additional studies should be performed in field plantations with the objective of confirming and evaluating morphological, physiological and biochemical characteristics of plants of C. trichotoma submitted to doses of $\mathrm{P}$.

\section{CONCLUSION}

- $\mathrm{P}$ and $\mathrm{K}$ both promotes increase in the growth and in photosynthetic ability of Cordia trichotoma seedlings, being recommended to the application of $450 \mathrm{mg} \mathrm{dm}^{-3}$ of $\mathrm{P}$ and $50 \mathrm{mg} \mathrm{dm}^{-3}$ of $\mathrm{K}$ for bigger growth in shoot height, stem diameter, leaf area, shoot and root dry matter. This combination also is indicated for bigger tenors of photosynthetic pigments, greater utilization of light energy by PSII and minor rate of energy loss by fluorescence of chlorophyll $a$.

- Fluorescence emission measurement of chlorophyll $a$ can be used to evaluate alterations in plant metabolism caused by low the availability of $P$, being the values of 0.76 and 172,5 for $F_{v} / F_{m}$ e $F_{0}$, respectively, considered adequate for healthful seedlings of Cordia trichotoma.

\section{REFERENCES}

ALVARES, C. A.; STAPE, J. L.; SENTElHAS, P. C.; GONÇALVES, J. L. de M.; SPAROVEK, G. Köppen's climate classification map for Brazil. Meteorologische Zeitschrift, Fast Track, v. 22, n. 6, p. 711-728, 2013.

ARAÚJO, S. A. DO C.; DEMINICIS, B. B. Fotoinibição da Fotossíntese. Revista Brasileira de Biociências, Porto Alegre, v. 4849, p. 463-472, 2009.

BAKER, N. R. Chlorophyll Fluorescence: A Probe of Photosynthesis In Vivo. Annual Review of Plant Biology, v. 59, n. 1, p. 89-113, 2008.

CADORIN, D. A.; MAlavASI U. C.; COUTINHO, P. W. R.; DRANSKI, J. A. L.; MALAVASI, M. de M. Metil jasmonato e flexões caulinares na rustificação e crescimento inicial de mudas de Cordia trichotoma. Cerne, Lavras, v. 21, n. 4, p. 657-664, 2015.

CORADIN, L.; SIMINSKI, A.; REIS, A. Espécies nativas da flora brasileira de valor econômico atual ou potencial: plantas para o futuroRegião Sul. Brasília: MMA, 2011. 934 p.

CROUS, K. Y.; ÓSVALDSSON, A.; ELLSWORTH, D. S. Is phosphorus limiting in a mature Eucalyptus woodland? Phosphorus fertilisation stimulates stem growth. Plant and Soil, v. 391, n. 1, p. 293-305, 2015.

EMBRAPA. CENTRO NACIONAL DE PESQUISA DE SOLOS. Sistema Brasileiro de Classificação de Solos. 3. ed. Brasília, 2013. p. 353.

FERREIRA, D. F. Sisvar: a computer statistical analysis system. Ciência e Agrotecnologia, Lavras, v. 35, n. 6, p. 1039-1042, 2011.

GERKE, J. The acquisition of phosphate by higher plants: Effect of carboxylate release by the roots. A critical review. Journal of Plant Nutrition and Soil Science, London, v. 178, n. 3, p. 351-364, 2015.

GONÇALVES, J. L. M.; WICHERT, M. C. P.; GAVA, J. L.; SERRANO, M. I. P. Soil fertility and growth of Eucalyptus grandis in Brazil under different residue management practices. Southern Hemisphere Forestry Journal, New Zealand, v. 69, n. 2, p. 95-102, 2008a.

GONÇALVES, J. L. M.; STAPE, J. L.; LACLAU, J. P.; BOUILLET, J. P; RANGER, J. Assessing the effects of early silvicultural management on long-term site productivity of fast-growing eucalypt plantations: The Brazilian experience. Southern Forests, v. 70, n. 2, p. 105-118, 2008b.

HISCOX, J. D.; ISRAELSTAM, G. F. A method for the extraction of chlorophyll from leaf tissue without maceration. Canadian Journal of Botany, v. 57, n. 12, p. 1332-1334, 1979.

JIANG, H. X.; TANG N.; ZHENG, J. G.; LI, Y.; CHEN, L.S. Phosphorus alleviates aluminum-induced inhibition of growth and photosynthesis in Citrus grandis seedlings. Physiologia Plantarum, v. 137, n. 3, p. 298-311, 2009. 
LICHTENTHALER, H. K. Chlorophylls and carotenoids: Pigments of photosynthetic biomembranes. Methods in Enzymology, v. 148, p. 350-382, 1987.

MARSCHNER, P. Mineral nutrition of higher plants. 3.ed. London, Elsevier, 2012. 651.p

OOSTERHUIS, D. M.; LOKA, D. A.; RAPER, T. B. Potassium and stress alleviation: Physiological functions and management of cotton. Journal of Plant Nutrition and Soil Science, v. 176, n. 3, p. 331-343, 2013.

PANDA, D.; SHARMA, S. G.; SARKAR, R. K. Chlorophyll fluorescence parameters, $\mathrm{CO}_{2}$ photosynthetic rate and regeneration capacity as a result of complete submergence and subsequent re-emergence in rice (Oryza sativa L.). Aquatic Botany, v. 88, n. 2, p. 127-133, 2008.

ROSSA, Ü. B.; ANGElo, A. C.; BOGNOLA, I. A.; WeStPhALEN, D. J.; MILANI, J. E. Fertilizante de liberação lenta no desenvolvimento de mudas de Eucalyptus grandis. Floresta, Curitiba v. 45, n. 1, p. 85, 2014.

SHEN, J.; YUAN, L.; ZHANG, J.; LI, H; BAI, Z; CHEN, X.; ZHANG, W.; ZHANG, F. Phosphorus Dynamics: From Soil to Plant. Plant Physiology, v. 156, n. 3, p. 997-1005, 2011.

SOUZA, N. H. de; MARCHETTI, M. E.; CARNEVALI, T. de O.; RAMOS, D. D.; SCALON, S. de P. Q.; SILVA, E. F. da. Estudo nutricional da canafístula (I): crescimento e qualidade de mudas em resposta à adubação com nitrogênio e fósforo. Revista Árvore, Viçosa, v. 37, n. 4, p. 717-724, 2013.

SOUZA, N. H. de; MARCHETTI, M. E.; CARNEVALI, T. de O.; RAMOS, D. D.; SCALON, S. de P. Q.; OLIVEIRA, M. T. de. Crescimento inicial de Stryphnodendron polyphylum (Mart.) em resposta à adubação com N e P. Cerne, Lavras, v. 20, n. 3, p. 441-447, 2014.

STAHL, J.; ERNANI, P. R.; GATIBONI, L. C.; CHAVE, D. M.; NEVES, C. U. Produção de massa seca e eficiência nutricional de clones de Eucalyptus dunnii e Eucalyptus benthamii em função da adição de doses de fósforo ao solo. Ciência Florestal, Santa Maria, v. 23, n. 2, p. 287-295, 2013.

SUN, O. J.; PAYN, T. W. Magnesium nutrition and photosynthesis in Pinus radiata: clonal variation and influence of potassium. Tree physiology, v. 19, n. 8, p. 535-540, 1999.

TAIZ, L.; ZEIGER, E. Plant Physiology. 5. ed. Porto Alegre: Artmed, 2013.

TEDESCO, M. J.; GIANELlO, C.; BISSANI, C.A.; BOHNEN, H.; VOLKWEISS, S.J. Análises de solos, plantas e outros materiais. 2. ed. Porto Alegre: UFRGS, 1995. 174p. (Boletim técnico, 5). 
FLORESTA, Curitiba, PR, v. 49, n. 1, p. 133-142, jan/mar 2019 Berghetti. A. L. P. et.al. 